\title{
EFFECT OF CHITOSAN COATING WITH THE ADDITION OF CARAWAY ESSENTIAL OIL AND BEESWAX ON OXIDATIVE STABILITY OF PETROVSKÁ KLOBÁSA SAUSAGE
}

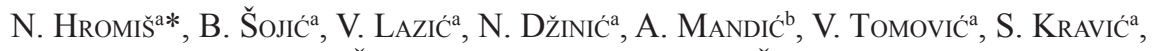 \\ S. ŠSKALJAC ${ }^{\mathrm{a}}, \mathrm{S}$. Popovića and D. ŠSuput ${ }^{\mathrm{a}}$ \\ ${ }^{a}$ Faculty of Technology, University of Novi Sad, Bulevar Cara Lazara 1, 21000 Novi Sad. Serbia \\ ${ }^{b}$ Institute of Food Technology, University of Novi Sad, Bulevar Cara Lazara 1, 21000 Novi Sad. Serbia
}

(Received: 10 November 2016; accepted: 16 January 2017)

\begin{abstract}
The aim of this paper was to examine the effect of chitosan coating with the addition of caraway essential oil and beeswax on lipid oxidation protection, as well as aroma and water content preservation of traditional dry fermented Petrovská klobása sausage.

During the entire storage period, TBARS index value in coated sausage was lower compared to the control $(\mathrm{P}<0.05)$. After two months of storage, TBARS index value in control and coated sausages were $0.94 \pm 0.04 \mathrm{mg} \mathrm{kg}^{-1}$ and $0.66 \pm 0.03 \mathrm{mg} \mathrm{kg}^{-1}$, while after seven months of storage, these values were $0.82 \pm 0.05 \mathrm{mg} \mathrm{kg}^{-1}$ and $0.67 \pm 0.02$ $\mathrm{mg} \mathrm{kg}{ }^{-1}$, respectively. While content of saturated aliphatic aldehydes increased in control sausage $(\mathrm{P}<0.05)$, it remained unchanged in coated sausage during 7 months of storage. Lipid oxidation protective effect could be correlated to higher marks for aroma of coated sausage during the entire storage period $(\mathrm{P}<0.05)$. Coating slowed moisture loss of coated sausage compared to the control $(\mathrm{P}<0.05)$.
\end{abstract}

Keywords: chitosan, coating, caraway oil, beeswax, dry fermented sausage, lipid oxidation

During manufacturing and storage of fermented sausages, intensive lipolytic and oxidative changes occur. Lipid oxidation leads to rancidity, discolouration, and accumulation of undesirable compounds, which affect sausage quality and may be harmful to human health (Šosıć et al., 2015). In addition to lipid oxidation, during storage of dry fermented sausages, different deteriorative physical-chemical processes occur, among them sausage dehydration. Moisture loss affects deterioration of sensory properties (wrinkled coating surface, dark colour, too hard consistency), as well as the economic effect of production, considering excessive loss of weight.

Researchers reported that chitosan can be used as edible film or coating for the protection of fish, meat, and meat products from lipid oxidation during storage, probably due to its good gas barrier properties (MoHAN et al., 2012). Often used solution is addition of plant extracts and essential oils as active compounds, where film acts as carrier for active component and enables its graduate release during time (QIU et al., 2014; НRомIš et al., 2015).

Although chitosan films show low permeability to gases, they lack resistance to water transmission. In order to improve water barrier properties of chitosan film, addition of different hydrophobic compounds showed considerable effect (THE et al., 2009; VARGAS et al., 2009; HROMIš et al., 2015).

In this paper, effect of chitosan coating with the addition of caraway essential oil and beeswax on shelf-life prolongation of traditional dry fermented Petrovac sausage (Petrovská

\footnotetext{
* To whom correspondence should be addressed.

Phone: +381214853702; fax: +381216350262; e-mail: nevenakrkic@gmail.com
} 
klobása) protected with Designation of Origin according to the Serbian law in 2007 (PETROvić et al., 2007) was investigated. At the end of drying process, Petrovac sausage was coated with composite coating in order to postpone lipid oxidation as well as water loss during 7 months of storage.

\section{Materials and methods}

\subsection{Materials}

1.1.1. Coating preparation. Chitosan coating was prepared by dissolving chitosan powder (crab shells, highly viscous, deacetylation degree approximately $80 \%$, Sigma-Aldrich Chemical Co., ST. Louis, Missouri, USA) in acetic acid $\left(\mathrm{CH}_{3} \mathrm{COOH}, 1 \% \mathrm{v} / \mathrm{v}\right.$ concentration). Chitosan powder was added to reach chitosan mass per volume ratio of $10 \mathrm{~kg} \mathrm{~m}^{-3}$. Solution was stirred overnight on a magnetic stirrer to dissolve chitosan. After dissolving chitosan, caraway essential oil (Herba doo, Belgrade, Serbia) and wetting agent Tween 20 (Superlab, Belgrade, Serbia) were added to the solution in $1 \%$ and $0.5 \%$ volume concentrations, respectively. Resulting emulsion was heated in a water bath to $60{ }^{\circ} \mathrm{C}$ and added to molten wax to obtain film forming emulsion with beeswax mass per volume ratio of $36 \mathrm{~kg} \mathrm{~m}^{-3}$ (Hromiš et al., 2015).

1.1.2. Sausage preparation and coating. Sausage preparation process was performed as described by KRKIĆ and co-workers (2012). One alteration was the drying process, which lasted 90 days, because manufacturing was performed in traditional conditions in rural households during winter months. Collagen casing "KOKO" with diameter $55 \mathrm{~mm}$ (Koteks Viscofan, Novi Sad, Serbia) was used for stuffing sausage.

After drying, sausages were coated with coating emulsion using a sponge brush as described by KRKIĆ and co-workers (2013a). Sausages were designated as control and coated sausage. After coating, sausages were stored for seven months at $15^{\circ} \mathrm{C}$ and $75 \% \mathrm{RH}$. Analyses were performed after drying (before coating), after 2 and 7 months of storage. All determinations were made on three samples (three different sausages) from each group (coated and control) in duplicate (two repetitions were done on each sausage).

\subsection{Methods}

1.2.1. Moisture, fat, and protein content. Chemical composition of sausages was determined according to appropriate ISO standards: ISO 1442:1997, ISO 1443:1973, and ISO 937:1978.

1.2.2. Fatty acid profile determination. Fatty acid profile was determined by gas chromatographic method with adequate preparation of samples described by KRKIĆ and coworkers (2013b). After extraction of lipids, fatty acid methyl esters were extracted and dissolved in $n$-hexane. Solution was injected into the GC (Varian, series 1400, Perkin-Elmer) with a packed column $(3 \mathrm{~m} \times 3.0 \mathrm{~mm}$, a stationary phase GP $10 \%$ SPTM- 2330 on inert carrier 100/120 Chromosorb WAW) and flame ionization detection was used (Perkin-Elmer, Waltham, Massachusetts, USA). Fatty acid methyl esters were identified by comparing retention times of the peaks in the sample with those of standard pure compounds (SigmaAldrich Chemical, St. Louis, Missouri, USA). Fatty acids methyl esters were quantified as percentage of total methyl esters. 
1.2.3. TBARS determination. TBARS test was performed using the method of BoTSOGLOU and co-workers (1994), with modifications according to MANDIĆ (2007). The test using spectrophotometer Jenway 6300 (Jenway, Felsted, United Kingdom) was described by KRKIĆ and co-workers (2013a). TBARS values were expressed as milligrams of malondialdehyde per kilogram of sample.

1.2.4. Aldehydes determination. Static headspace gas chromatographic (SHS-GC) analyses were performed on Agilent 7890A GC System (Agilent Technologies, Santa Clara, California, USA) equipped with a capillary split/split less inlet, total electronic pneumatic control of gas flow, headspace auto sampler, and FID. Static headspace (SHS) sampling was performed with the headspace sampler, CombiPAL System (CTC Analytics, Zwingen, Switzerland). A $2.5 \mathrm{ml} \mathrm{HS}$ syringe for CombiPAL was used, for the injection of $2.0 \mathrm{ml}$ of vapour phase from the $10 \mathrm{ml}$ headspace vials. Chromatographic conditions and aldehydes standard preparation was performed according to the MANDIĆ and co-workers (2012). Homogenized sample was accurately weighed $(2.00 \mathrm{~g})$ into $10 \mathrm{ml}$ screw-capped headspace vial.

1.2.5. Sensory evaluation of aroma. Sensory evaluation was performed using quantitative descriptive analysis (ISO 8586-1, 1993; ISO 4121, 2003; ISO 8586-2, 2008) according to the method described previously by ŠoJIć and co-workers (2015), using a scale from 0 to 5, with a sensitivity threshold of 0.25 points. Each mark means distinctive quality level, described as follows: 5: extraordinary, typical, optimal quality; 4: observable deviations or insignificant quality defects; 3 : drawbacks and defects of quality; 2 : distinct to very distinct drawbacks and defects of quality; 1: fully changed, atypical properties, product unacceptable; 0: visible mechanical or microbiological contamination, atypical product.

1.2.6. Statistical analysis. Statistical analysis was carried out using STATISTICA 8.0 (StatSoft, Inc., Tulsa, OK, USA). All data were presented as mean value with their standard deviation indicated (mean $\pm \mathrm{SD}$ ). Variance analysis (ANOVA) was performed, with a confidence interval of $95 \%$ ( $\mathrm{P}<0.05)$. Means were compared by Duncan's multiple range test.

\section{Results and discussion}

In this experiment, moisture content (showed in Table 1) at the end of drying was $29.81 \pm 0.05 \%$. After reaching $35 \%$ or less moisture content (SL. GLASNIK RS, 94/2015), further moisture loss is undesirable, because it affects sensory quality and sausage appears too dry, tough, and wrinkled. During storage, moisture content decreased both in control and chitosan coated sausage. After 2 months of storage, moisture content of control sausage was $22.19 \pm 0.06 \%$, while for chitosan coated sausage moisture content was higher $(\mathrm{P}<0.05), 24.00 \pm 0.05 \%$. At the end of storage, moisture contents for control and coated sausages were $15.21 \pm 0.08 \%$ and $16.27 \pm 0.08 \%$ and were statistically different $(\mathrm{P}<0.05)$. Following decrease in moisture content, contents of fat and protein increased during storage in both tested sausages, and this increase was more pronounced in uncoated sausage (Table 1). Coating sausage with chitosan layer slowed down the moisture loss, but moisture loss was still significant. 
Table 1. Moisture, fat and protein contents of control and coated sausages during storage, $\%$

\begin{tabular}{lcccccc}
\hline & End of drying & \multicolumn{2}{c}{2 months of storage } & & \multicolumn{2}{c}{7 months of storage } \\
\cline { 3 - 4 } \cline { 6 - 7 } & & Unpacked & Chitosan coated & & Unpacked & Chitosan coated \\
\hline Moisture & $29.81 \pm 0.05^{\mathrm{a}}$ & $22.19 \pm 0.06^{\mathrm{c}}$ & $24.00 \pm 0.05^{\mathrm{b}}$ & & $15.21 \pm 0.08^{\mathrm{e}}$ & $16.27 \pm 0.08^{\mathrm{d}}$ \\
Fat & $28.58 \pm 0.27^{\mathrm{d}}$ & $34.81 \pm 0.23^{\mathrm{b}}$ & $32.68 \pm 0.18^{\mathrm{c}}$ & & $35.47 \pm 0.23^{\mathrm{a}}$ & $34.80 \pm 0.15^{\mathrm{b}}$ \\
Protein & $31.95 \pm 0.33^{\mathrm{d}}$ & $34.29 \pm 0.15^{\mathrm{b}}$ & $33.71 \pm 0295^{\mathrm{c}}$ & & $39.43 \pm 0.29^{\mathrm{a}}$ & $39.84 \pm 0.15^{\mathrm{a}}$ \\
\hline
\end{tabular}

Different letters ${ }^{\text {abcd }}$ within the same row mark significantly different means with $95 \%$ probability $(\mathrm{P}<0.05)$.

Fatty acid profile of control and coated sausage during storage is shown in Table 2 . In accordance with literature data, content of oleic acid (C18:1) was highest in fatty acid profile (ANSORENA \& AstiasARÁn, 2004; Rubio et al., 2008). These results correspond well with our previous results (KRKIĆ et al., 2013a, 2013b). Special consideration should be given to unsaturated fatty acids (linoleic C18:2 and linolenic C18:3), knowing that they belong to the group of essential fatty acids, and that they are highly susceptible to oxidative changes. Obtained values for linoleic and linolenic acids in Petrovac sausage are similar to the results in similar meat products (VAlEnCIA et al., 2006; RuBio et al., 2008). Linoleic and linolenic acid contents obtained in this study are slightly higher compared to our previous results for Petrovac sausage (KRKIĆ et al., 2013a, 2013b).

Table 2. Fatty acid profile in control and coated sausages during storage, $\%$

\begin{tabular}{|c|c|c|c|c|c|}
\hline \multirow[t]{2}{*}{ Fatty acids } & \multirow[t]{2}{*}{ End of drying } & \multicolumn{2}{|c|}{2 months of storage } & \multicolumn{2}{|c|}{7 months of storage } \\
\hline & & Control & Coated & Control & Coated \\
\hline $\mathrm{C} 14: 0$ & $2.60 \pm 0.06^{\mathrm{a}}$ & $2.79 \pm 0.03^{\mathrm{a}}$ & $2.20 \pm 0.20^{\mathrm{b}}$ & $2.78 \pm 0.19^{\mathrm{a}}$ & $2.15 \pm 0.10^{\mathrm{b}}$ \\
\hline C16:0 & $25.15 \pm 0.35^{\mathrm{a}}$ & $25.73 \pm 1.21^{\mathrm{a}}$ & $25.20 \pm 0.38^{\mathrm{a}}$ & $25.75 \pm 0.05^{\mathrm{a}}$ & $25.35 \pm 0.65^{\mathrm{a}}$ \\
\hline C18:0 & $12.10 \pm 0.01^{\mathrm{b}}$ & $12.00 \pm 0.02^{\mathrm{b}}$ & $11.84 \pm 0.01^{\mathrm{b}}$ & $13.14 \pm 0.36^{\mathrm{a}}$ & $13.54 \pm 0.65^{\mathrm{a}}$ \\
\hline C16:1 & $4.50 \pm 0.14^{\mathrm{ab}}$ & $4.06 \pm 0.15^{\mathrm{c}}$ & $4.81 \pm 0.36^{\mathrm{a}}$ & $4.05 \pm 0.11^{\mathrm{c}}$ & $4.18 \pm 0.13^{\mathrm{bc}}$ \\
\hline C18:1 & $31.83 \pm 0.05^{\mathrm{a}}$ & $31.82 \pm 0.49^{\mathrm{a}}$ & $31.79 \pm 0.21^{\mathrm{a}}$ & $32.10 \pm 0.09^{\mathrm{a}}$ & $31.72 \pm 0.53^{\mathrm{a}}$ \\
\hline C20:1 & $0.50 \pm 0.05^{\mathrm{a}}$ & $0.28 \pm 0.03^{\mathrm{c}}$ & $0.43 \pm 0.02^{\mathrm{b}}$ & $0.41 \pm 0.03^{\mathrm{b}}$ & $0.38 \pm 0.02^{\mathrm{b}}$ \\
\hline C18:2 & $20.80 \pm 0.10^{\mathrm{ab}}$ & $21.00 \pm 1.00^{\mathrm{a}}$ & $21.44 \pm 0.39^{\mathrm{a}}$ & $19.39 \pm 0.42^{\mathrm{c}}$ & $19.94 \pm 0.41^{b c}$ \\
\hline C18:3 & $1.98 \pm 0.03^{\mathrm{b}}$ & $1.95 \pm 0.15^{\mathrm{b}}$ & $2.08 \pm 0.01^{\mathrm{ab}}$ & $2.04 \pm 0.03^{\mathrm{ab}}$ & $2.14 \pm 0.08^{\mathrm{a}}$ \\
\hline$\sum \mathrm{SFA}$ & $39.85 \pm 0.29^{\mathrm{bc}}$ & $40.52 \pm 1.24^{\mathrm{ab}}$ & $39.24 \pm 0.57^{\mathrm{c}}$ & $41.65 \pm 0.53^{\mathrm{a}}$ & $41.03 \pm 0.10^{\mathrm{ab}}$ \\
\hline$\sum$ UFA & $60.12 \pm 0.33^{\mathrm{ab}}$ & $59.43 \pm 1.23^{b c}$ & $60.76 \pm 0.57^{\mathrm{a}}$ & $58.35 \pm 0.53^{\mathrm{c}}$ & $58.97 \pm 0.10^{\mathrm{bc}}$ \\
\hline$\sum$ PUFA & $23.29 \pm 0.09^{\mathrm{ab}}$ & $23.27 \pm 0.86^{\mathrm{ab}}$ & $23.72 \pm 0.40^{\mathrm{a}}$ & $21.80 \pm 0.36^{\mathrm{c}}$ & $22.69 \pm 0.54^{\mathrm{bc}}$ \\
\hline
\end{tabular}

Different letters ${ }^{\text {abcd }}$ within the same row mark significantly different means with $95 \%$ probability $(\mathrm{P}<0.05)$.

At the end of drying, TBARS index value in the sausage was $0.40 \pm 0.04 \mathrm{mg} \mathrm{kg}^{-1}$ (Fig. 1). This value is in agreement with literature data for TBARS index values in dry fermented sausages (Ansorena \& Astiasarán, 2004; VAlencia et al., 2006). During storage, value of TBARS in control and coated sausage increased, indicating oxidative changes in lipids, but in coated sausage this increase was less pronounced $(\mathrm{P}<0.05)$ during the entire storage period. After two months of storage, TBARS index value in control and chitosan coated sausages were $0.94 \pm 0.04 \mathrm{mg} \mathrm{kg}^{-1}$ and $0.66 \pm 0.03 \mathrm{mg} \mathrm{kg}^{-1}$, respectively, and were significantly different $(\mathrm{P}<0.05)$. Recorded difference was probably due to protective function of applied chitosan 
coating against deteriorative oxidative changes. In addition, fat content after two months of storage was lower in coated sausage. After seven months of storage, TBARS index value in control sausage decreased to $0.82 \pm 0.05 \mathrm{mg} \mathrm{kg}^{-1}$, probably due to interaction of TBARS with degradation products formed in the process of ripening, such as amino acids, sugars, and nitrites (ANSORENA \& ASTIASARÁN, 2004), while TBARS index value in coated sausage remained statistically unchanged $(\mathrm{P}>0.05), 0.67 \pm 0.02 \mathrm{mg} \mathrm{kg}^{-1}$. Comparing results with our previous work on chitosan-caraway oil coated Petrovac sausage, it can be seen that applied coating with beeswax in this experiment showed more pronounced protective effect against lipid oxidation compared to chitosan coating with essential oil without beeswax. This could be the result of a certain contribution of beeswax to antioxidant activity of chitosan-caraway coating or better coating distribution on the product surface, coating-products interaction, and less pronounced changes in product moisture content during storage (ANILAKUMAR \& KHANUM, 2009).

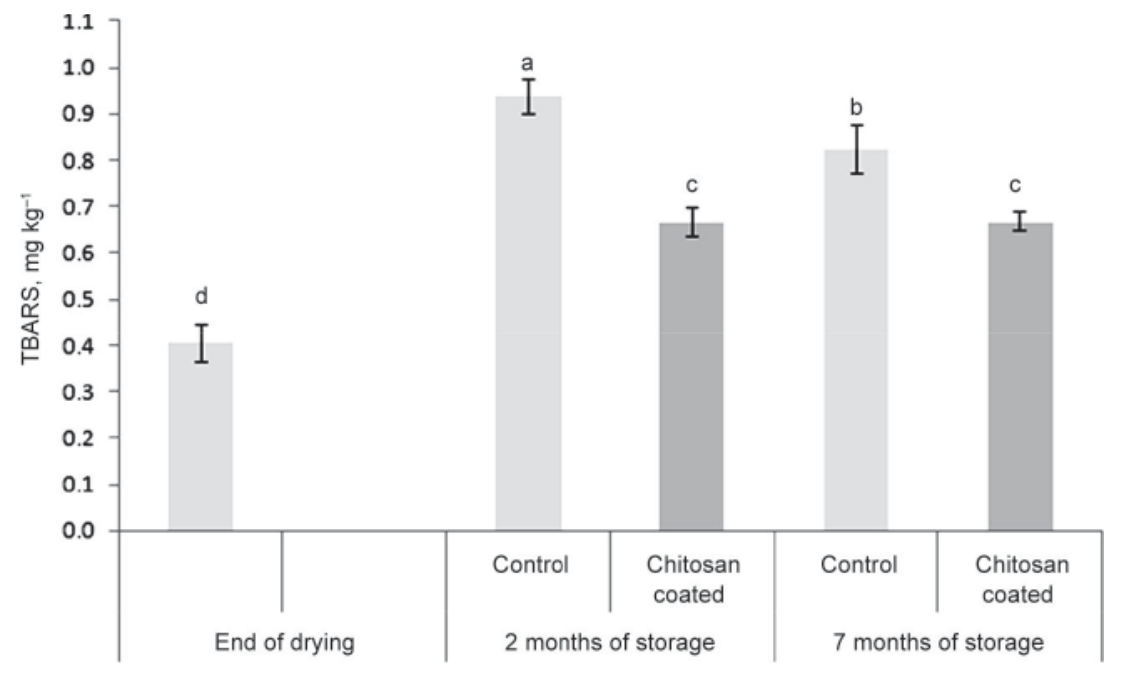

Fig. 1. TBARS ( $\mathrm{mg} \mathrm{kg}^{-1}$ ) values for control and chitosan coated sausages during storage. Different letters ${ }^{\text {abcd }}$ mark significantly different means with $95 \%$ probability $(\mathrm{P}<0.05)$

Table 3. Aldehyde content in control and coated sausages during storage, $\mu \mathrm{g} \mathrm{g}^{-1}$

\begin{tabular}{|c|c|c|c|c|c|}
\hline \multirow[t]{2}{*}{ Aldehydes } & \multirow[t]{2}{*}{ End of drying } & \multicolumn{2}{|c|}{2 months of storage } & \multicolumn{2}{|c|}{7 months of storage } \\
\hline & & Unpacked & Chitosan coated & Unpacked & Chitosan coated \\
\hline Propanal & $2.51 \pm 0.13^{\mathrm{c}}$ & $3.29 \pm 0.06^{\mathrm{b}}$ & $2.57 \pm 0.05^{\mathrm{c}}$ & $3.49 \pm 0.01^{\mathrm{a}}$ & $2.44 \pm 0.07^{\mathrm{c}}$ \\
\hline Pentanal & $0.98 \pm 0.04^{\mathrm{b}}$ & $1.08 \pm 0.11^{\mathrm{b}}$ & $1.01 \pm 0.02^{\mathrm{b}}$ & $1.29 \pm 0.06^{\mathrm{a}}$ & $1.13 \pm 0.15^{\mathrm{b}}$ \\
\hline Hexanal & $0.64 \pm 0.02^{\mathrm{b}}$ & $0.65 \pm 0.02^{\mathrm{b}}$ & $0.64 \pm 0.01^{\mathrm{b}}$ & $0.74 \pm 0.01^{\mathrm{a}}$ & $0.63 \pm 0.01^{\mathrm{b}}$ \\
\hline Heptanal & $0.59 \pm 0.01^{\mathrm{b}}$ & $0.60 \pm 0.01^{\mathrm{ab}}$ & $0.60 \pm 0.02^{\mathrm{ab}}$ & $0.62 \pm 0.01^{\mathrm{a}}$ & $0.61 \pm 0.01^{\mathrm{ab}}$ \\
\hline Octanal & $1.05 \pm 0.04^{\mathrm{c}}$ & $1.65 \pm 0.08^{\mathrm{a}}$ & $1.33 \pm 0.16^{\mathrm{b}}$ & $1.68 \pm 0.12^{\mathrm{a}}$ & $1.13 \pm 0.03^{\mathrm{c}}$ \\
\hline
\end{tabular}

Different letters ${ }^{\text {abc }}$ within the same row mark significantly different means with $95 \%$ probability $(\mathrm{P}<0.05)$.

Propanal content was highest in the total aldehydes content in the sausage after drying, as well as in both analysed sausages during storage (Table 3). High values for propanal 
content is characteristic for Petrovska klobasa (KRKIĆ et al., 2013a, 2013b), probably due to relatively high content of linolenic acid in the sausage. After propanal, aldehydes contents may be represented in decreasing order: octanal $>$ pentanal $>$ hexanal $>$ heptanal. Contents of pentanal and hexanal, typical products of oxidative degradation of linoleic acid, were in the range of values reported for similar products by authors ANSORENA and ASTIASARÁN (2004) and VALENCIA and co-workers (2006).

During storage, content of all analysed aldehydes increased in control sausage $(\mathrm{P}<0.05)$, while in coated sausage, aldehydes content remained unchanged during 7 months of storage. Comparing to our previous results (KRKIć et al., 2013a, 2013b), analysed aldehydes contents show more pronounced effect of chitosan coating with addition of essential oil and beeswax compared to chitosan coating with essential oil without beeswax.

Sensory evaluation is one of the key elements in consideration of product acceptability by consumers. Sensory evaluation of control and chitosan coated sausages after drying and during storage is presented in Table 4. It can be noted from Table 4 that there was no significant difference $(\mathrm{P}>0.05)$ between sensory evaluation of colour and texture between the two sausages during storage, and marks for both parameters decreased during storage for both tested sausages. Aroma of both uncoated and chitosan coated sausages also deteriorated during storage. From $4.72 \pm 0.13$ at the end of drying, control sausage aroma was evaluated $4.37 \pm 0.12$ after two months of storage and $3.51 \pm 0.04$ after seven months of storage. Chitosan coated sausage was evaluated $4.53 \pm 0.05$ after two months of storage and $3.75 \pm 0.12$ after seven months of storage. Higher sensory evaluation marks $(\mathrm{P}<0.05)$ for chitosan coated sausage aroma are probably due to lower lipid oxidative changes in the chitosan coated sausage.

Table 4. Sensory evaluation of control and coated sausages during storage

\begin{tabular}{|c|c|c|c|c|c|}
\hline & \multirow[t]{2}{*}{ End of drying } & \multicolumn{2}{|c|}{2 months of storage } & \multicolumn{2}{|c|}{7 months of storage } \\
\hline & & Unpacked & Chitosan coated & Unpacked & Chitosan coated \\
\hline Colour & $4.62 \pm 0.08^{\mathrm{a}}$ & $4.37 \pm 0.12^{\mathrm{b}}$ & $4.43 \pm 0.08^{\mathrm{b}}$ & $3.67 \pm 0.21^{\mathrm{c}}$ & $4.00 \pm 0.13^{\mathrm{c}}$ \\
\hline Texture & $4.46 \pm 0.16^{\mathrm{a}}$ & $4.03 \pm 0.24^{\mathrm{bc}}$ & $4.30 \pm 0.27^{\mathrm{ab}}$ & $3.73 \pm 0.20^{\mathrm{c}}$ & $3.80 \pm 0.33^{\mathrm{c}}$ \\
\hline Aroma & $4.72 \pm 0.13^{\mathrm{a}}$ & $4.37 \pm 0.12^{\mathrm{c}}$ & $4.53 \pm 0.05^{\mathrm{b}}$ & $3.52 \pm 0.04^{\mathrm{e}}$ & $3.75 \pm 0.12^{\mathrm{d}}$ \\
\hline
\end{tabular}

Different letters ${ }^{\text {abcd }}$ within the same row mark significantly different means with $95 \%$ probability $(\mathrm{P}<0.05)$.

\section{Conclusions}

During storage of seven months, coating based on chitosan with the addition of caraway essential oil and beeswax resulted in the reduction of lipid oxidative changes measured as TBARS index value and saturated aliphatic aldehydes contents. Apart from lipid oxidation protective effect, composite coating influenced aroma preservation and lower moisture loss of Petrovac sausage during storage.

This study was supported by the Ministry of Education, Science and Technological Development of the Republic of Serbia, Project No. TR31032, as well as the Provincial secretariat for higher education and scientific research, Autonomous Province of Vojvodina, Republic of Serbia, Project No. 142-451-3626/2016-01. 


\section{References}

Anilakumar, K.R. \& Khanum, F. (2009): Effect of bees wax polyphenols on hexachlorocyclohexane-induced oxidative stress in rat liver. Int. J. Integr. Biol (IJIB), 7, 156-159.

Ansorena, D. \& Astiasarán, I. (2004): Effect of storage and packaging on fatty acid composition and oxidation in dry fermented sausages made with added olive oil and antioxidants. Meat Science, 67, 237-244.

Botsoglou, N.A. Fletouris, D.J. Papageorgiou,G.E., Vassilopoulos, V.N., Mantis, A.J. \&Trakatellis, A.G. (1994): Rapid, sensitive and specific thiobarbituric acid methor for measurement of lipid peroxidatipon in animal tissue, food and feedstuff samples, J. Agr. Food Chem., 42, 1931-1937.

Hromiš, N., Lazić, V., Markov, S., Vaštag, Ž., Popović, S., Šuput, D., Džinić, N., Velićanski, A. \& Popović, Lu. (2015): Optimization of chitosan biofilm properties by addition of caraway essential oil and beeswax. J. Food Eng., 158, 86-93.

ISO (1978): Meat and meat products. Determination of nitrogen content (reference method). International Organisation for Standardisation, Geneva, Switzerland, No. ISO 937, 3 pages.

ISO (1973): Meat and Meat Products. Determination of total fat content. International Organisation for Standardisation, Geneva, Switzerland, No. ISO 1443, 2 pages.

ISO (1993): Sensory analysis. General guidance for the selection, training and monitoring of assessors - Part 1: Selected assessors. International Organisation for Standardisation, Geneva, Switzerland, No. ISO 8586-1, 24 pages.

ISO (1997): Meat and meat products - Determination of moisture content (reference method), International Organization for Standardization, Geneva, Switzerland, No. ISO 1442, 4 pages.

ISO. (2003): Sensory analysis. Guidelines for the use of quantitative response scales. International Organisation for Standardisation, Geneva, Switzerland, No. ISO 4121, 9 pages.

ISO (2008): Sensory analysis. General guidance for the selection, training and monitoring of assessors - Part 2: Expert sensory assessors. International Organisation for Standardisation Geneva, Switzerland, No. ISO85862, 15 pages.

Krkić, N., Lazić, V., Savatić, S., Šojić, B., Petrović, Lu. \& Šuput, D. (2012): Application of chitosan coating with oregano essential oil on dry fermented sausage. Properties of chitosan-laminated collagen film. J. Food Nutr. Res., 51, 60-68.

Krkić, N., Šojić, B., Lazić, V., Petrović, Lu., Mandić, A., Sedej, I., Tomović, V. \& Džinić, N. (2013a): Effect of chitosan-caraway coating on lipid oxidation of traditional dry fermented sausage. Food Control, 32, 719-723.

Krkić, N., Šojić, B., Lazić, V., Petrović, Lu., Mandić, A., Sedej, I. \& Tomović, V. (2013b): Lipid oxidative changes in chitosan-oregano coated traditional dry fermented sausage Petrovská klobása. Meat Science, 93, 767-770.

Mandić, A. (2007): Antioksidativna svojstva ekstrakata semena sorti belog grožđa (Antioxidant activities of grape seed extracts from white grape varieties). Ph. D. Thesis, University of Novi Sad, Serbia, pp. 34-44.

Mandić, A., SedEJ, I., SAKač, M. \& MišAn, A. (2012): Static headspace gas chromatographic method for aldehydes determination in crackers. Food Anal. Method., 6, 61-68.

Mohan, C.O., Ravishankar, C.N., Lalitha, K.V. \& Srinivasa Gopal, T.K. (2012): Effect of chitosan edible coating on the quality of double filleted Indian oil sardine (Sardinella longiceps) during chilled storage. Food Hydrocolloid., 26, 167-174.

Petrović, Lu., Džinić, N., Tomović, V., Ikonić, P. \& TAsić, T. (2007): Code of practice registered geographical indication Petrovská klobása. Republic of Serbia: Intellectual Property Office, Decision No. 9652/06 G-03/06, 71 pages.

Qiu, X., Chen, S., Liu, G. \& YANG, Q. (2014): Quality enhancement in the Japanese sea bass (Lateolabrax japonicas) fillets stored at $4{ }^{\circ} \mathrm{C}$ by chitosan coating incorporated with citric acid or licorice extract. Food Chem., 162, $156-160$

Rubio, B., Martínez, B., García-Cachán, M., Rovira, J. \& Jaime, I. (2008): Effect of the packaging method and the storage time on lipid oxidation and colour stability on dry fermented sausage salchichón manufactured with raw material with a high level of mono- and polyunsaturated fatty acids. Meat Sci., 80, 1182-1187.

SL. GLASNIK RS (2015): Pravilnik o kvalitetu usitnjenog mesa, poluproizvoda od mesa i proizvoda od mesa. (Rule book on the quality of ground meat, semi-finished meat and meat products) Official Gazette RS, 94/2015, 48 pages. 
Šojić, B., Tomović, V., Kocić-Tanackov, S., Škaljac, S., Ikonić, P., Džinić, N., Živković, N., Jokanović, M., Tasić, T. \& KRAVIĆ, S. (2015): Effect of nutmeg (Myristica fragrans) essential oil on the oxidative and microbial stability of cooked sausage during refrigerated storage. Food Control, 54, 282-286.

The, P.D., Debeaufort, F., Voilley, A. \& Luu, D. (2009): Influence of hydrocolloid nature on the structure and functional properties of emulsified edible films. Food Hydrocolloid., 23, 691-699.

Valencia, I., Ansorena, D. \& Astiasarán, I. (2006): Stability of linseed and antioxidants containing dry fermented sausages: a study of the lipid fraction during different storage conditions. Meat Sci., 73, 269-277.

Vargas, M., Albors, A., Chiralt, A. \& Gonzalez-Martinez, C. (2009): Characterization of chitosan-oleic acid composite films. Food Hydrocolloid., 23, 536-547. 